Portland State University

PDXScholar

Mechanical and Materials Engineering Faculty

Publications and Presentations

Mechanical and Materials Engineering

6-15-2021

\title{
Impact of Green and White Roofs on Air Handler Filters and Indoor Ventilation Air
}

Pradeep Ramasubramanian

Portland State University, pradeep2@pdx.edu

Irvan Luhung

Singapore Center for Environmental Life Sciences Engineering (SCELSE)

Serene B. Y. Lim

Singapore Center for Environmental Life Sciences Engineering (SCELSE)

Stephan C. Schuster

Singapore Center for Environmental Life Sciences Engineering (SCELSE)

Olyssa Starry

Portland State University, ostarry@pdx.edu

See next page for additional authors

Follow this and additional works at: https://pdxscholar.library.pdx.edu/mengin_fac

Part of the Materials Science and Engineering Commons

Let us know how access to this document benefits you.

\section{Citation Details}

Ramasubramanian, Pradeep; Luhung, Irvan; Lim, Serene B. Y.; Schuster, Stephan C.; Starry, Olyssa; and Gall, Elliott T., "Impact of Green and White Roofs on Air Handler Filters and Indoor Ventilation Air" (2021). Mechanical and Materials Engineering Faculty Publications and Presentations. 353.

https://pdxscholar.library.pdx.edu/mengin_fac/353

This Post-Print is brought to you for free and open access. It has been accepted for inclusion in Mechanical and Materials Engineering Faculty Publications and Presentations by an authorized administrator of PDXScholar.

Please contact us if we can make this document more accessible: pdxscholar@pdx.edu. 


\section{Authors}

Pradeep Ramasubramanian, Irvan Luhung, Serene B. Y. Lim, Stephan C. Schuster, Olyssa Starry, and Elliott T. Gall 


\section{Impact of green and white roofs on air handler filters and indoor 2 ventilation air}

3

4

5 Pradeep Ramasubramanian

6 Portland State University, 1825 SW Broadway, Portland, OR 97201

7

$8 \quad$ Irvan Luhung

9 Singapore Center for Environmental Life Sciences Engineering (SCELSE), 60 Nanyang Drive, 10 SBS-01N-27, Singapore 637551

11

12 Serene B.Y. Lim

13 Singapore Center for Environmental Life Sciences Engineering (SCELSE), 60 Nanyang Drive, 14 SBS-01N-27, Singapore 637551

15

16 Stephan C. Schuster

17 Singapore Center for Environmental Life Sciences Engineering (SCELSE), 60 Nanyang Drive, 18 SBS-01N-27, Singapore 637551

19

20 Olyssa Starry

21 Portland State University, 1825 SW Broadway, Portland, OR 97201

22

23 Elliott T. Gall

24 Portland State University, 1825 SW Broadway, Portland, OR 97201

25

$26 *$ Corresponding author: Elliott T. Gall, gall@pdx.edu 
Rooftop surfaces near building outdoor air intakes may contribute to the mass loading on filters and 29 compounds emitted to ventilation air downstream of the filter. In laboratory analyses, we characterized 30 microbial composition, primary volatile organic compound (VOC) emissions, ozone removal rates, and 31 VOC emissions in the presence of ozone on filters collected from air handlers located on the green and 32 white roof sections of a big-box retail store. Total DNA masses per area of filter were $26.3 \pm 11.9 \mathrm{ng} \mathrm{cm}^{-2}$ 33 and $6.3 \pm 6.5 \mathrm{ng} \mathrm{cm}^{-2}$ for green and white roof filters respectively, with higher mass observed in winter 34 compared to the fall season. Of eight VOCs quantified at constant $23{ }^{\circ} \mathrm{C}$ and $50 \% \mathrm{RH}$ across both seasons, 35 fluxes of m/z 33.02 (putatively attributed to methanol) dominated VOC emissions for green, $10.96 \pm 3.09$ $36 \mu \mathrm{mol} \mathrm{m}{ }^{-2} \mathrm{hr}^{-1}$, white, $12.02 \pm 3.41 \mu \mathrm{mol} \mathrm{m} \mathrm{hr}^{-1}$, and unused filters, $5.64 \pm 1.08 \mu \mathrm{mol} \mathrm{m}^{-2} \mathrm{hr}^{-1}$. Ozone 37 removal across all filters varied from $3.5 \% \pm 2.8 \%$ to $14 \% \pm 2.8 \%$, depending on temperature and $\mathrm{RH}$ 38 condition. Fluxes of eight quantified VOCs were lower in the presence of ozone, apart from $\mathrm{m} / \mathrm{z} 69.07$ 39 (putatively attributed to isoprene), where the presence of $\sim 180 \mathrm{ppb}$ inlet ozone resulted in increased fluxes 40 by a factor of $\sim 2.4$. A steady-state mass balance predicted increases in ventilation air methanol levels by 41 green roof filters ranging $0.10 \mu \mathrm{g} \mathrm{m}^{-3}$ to $19.44 \mu \mathrm{g} \mathrm{m}^{-3}$, depending on filter face velocity and filter geometry.

\section{$42 \quad \underline{\text { Keywords }}$}


Green roof implementation has been incentivized in many cities for their purported environmental,

46 social and economic benefits such as storm-water management, building energy savings and reducing urban

47 heat island effect ${ }^{1-5}$. Benefits to urban outdoor air quality from greenery and green roofs are also claimed, ${ }^{6}$

48 but recent studies suggest impacts may be modest $^{7-9}$. One explored avenue by which green roofs may affect

49 exposure to air pollution is by altering indoor air quality. For example, as outdoor air is transported across

50 green roof surfaces, particles from the substrate and vegetation may suspend and be entrained in the local

51 rooftop air flow. Since outdoor air intake for buildings is frequently sited on rooftops, the particle-laden

52 rooftop air flow may trap green roof particles onto rooftop filtration systems. A relatively unexplored

53 connection between green roofs and air pollution exposure is via heating, ventilation, and air conditioning

54 (HVAC) filters that process outdoor ventilation air entering from a green roof.

Loading of biotic matter on HVAC filters may alter the air quality of outdoor air ventilation. ${ }^{10}$ For

56 example, HVAC filters can be sources of indoor particles which can be composed of whole or fragmented

57 abiotic and biotic matter ${ }^{11}$. Loaded filters can also contain microbes that can impact indoor air through the

58 release of fungal spores from filters ${ }^{12}$ due to turbulence and other microbial discharge mechanisms. The

59 presence of microbes is mediated by environmental conditions; over a 14 day period of high relative

60 humidity (RH), Möritz et al. ${ }^{12}$ show microbes from filters enter the indoor environment; and to prevent

61 fungal growth on filters, control of both temperature and $\mathrm{RH}$ were required ${ }^{13}$.

62 Loaded filters can act as a source of volatile organic compounds (VOCs) to the indoor environment. A

63 field study of secondary air filters in a multi-story office building found indoor VOCs related to fungal

64 metabolic processes, and traced the source to fungal loading of filters ${ }^{14}$. As filter operational times increase,

65 particle loadings increase which results in increased surface area for sorption/desorption processes ${ }^{15}$.

66 Compounds such as carboxylic acids, aldehydes, terpenes and nitrogen-containing organic compounds are

67 shown to be released from dust accumulated on filters ${ }^{16,17}$. Higher concentrations of formaldehyde, 
acetaldehyde and acetone were found in loaded filters compared to unused filters, with acetone concentrations increasing as filters becomes increasingly loaded ${ }^{18}$.

As filter loading increases with run-time, filters remove greater quantities of ozone $\left(\mathrm{O}_{3}\right)^{19}$, a common urban air pollutant. Prior work has characterized ozone removal to loaded HVAC filters from office spaces $^{20}$, residential and commercial filters ${ }^{21}$, dusty and sooty filters ${ }^{22}$, and to green roof and white roof filters ${ }^{10}$. Ozone removal via the Criegee mechanism leads to carbonyl formation; ${ }^{23}$ a linear correlation can be made for carbonyl generation and ozone removal, when normalized for organic carbon mass on filters ${ }^{24}$. Ozonolysis products, including formaldehyde, acetaldehyde, acetone, and 4-oxopentanal are elevated downstream of filters laden with particles from vegetation and diesel emissions ${ }^{25}$. Some products, including formaldehyde, are emitted in proportion to $\mathrm{RH}$ level. ${ }^{26}$ Different plant species variably produce isoprene $\mathrm{e}^{27}$ and terpenes, ${ }^{28}$ organic compounds that are reactive with ozone. If these reactive organics are present on HVAC filters, surface reactions with ozone can lead to the formation of secondary organic aerosols ${ }^{29-31}$

In this manuscript, we examine the impact of loaded filters collected from a rooftop with vegetated (green roof) and non-vegetated (white roof) areas to investigate the effect of surrounding rooftop type on filter loading and the ensuing impact on VOC and particle emissions from filters. We characterize the microbial loadings on filters as well as identify the emissions of VOCs in the absence of ozone (primary VOC emissions), ozone removal rates, and emissions in the presence of ozone in a laboratory chamber apparatus. These analyses are conducted for filters collected from the field site during the fall and winter season. Despite the growing body of evidence linking HVAC filter quality to indoor air, to our knowledge, this is the first study to explore microbial composition on filters, characterize the VOC fluxes in the absence and presence of ozone, and report ozone removal rates for filters across various temperature and $\mathrm{RH}$ conditions and multiple seasons.

\section{Material and Methods}

\subsection{Field Site}


The field site is in north Portland, OR, USA at the roof of a big-box retail store. The rooftop is

93 comprised of three extensive green roof sections varying according to substrate depth, $\left(\sim 3600 \mathrm{~m}^{2}\right.$ of total

94 green roof area) and a 'white' roof section $\left(\sim 5400 \mathrm{~m}^{2}\right)$ covered only in white waterproof membrane totaling

95 a combined rooftop area of $9,000 \mathrm{~m}^{2}$ and shown in figure S1. The green roof design varies somewhat by

96 section but is generally comprised of a scoria-dominated substrate over a capillary fabric and waterproofing

97 membrane. The plant community is a mixture of succulent and herbaceous plants that were both planted

98 and introduced; dominant species include Erodium cicutarium, Plectritis congesta, Phedmus

99 takesimensis, Sedum rupestre 'Angelina', Trifolium repens, and Vulpia sp. As much as $20 \%$ of the roof 100 coverage was classified as rock/gravel. The field site is surrounded by urban surfaces to the south, vegetated 101 surfaces and urban greenery to the north and a major interstate highway (I-5) roughly $\sim 1000 \mathrm{~m}$ to the west 102 of the field site. Air handling units (AHU) from which filters were taken were chosen based on their 103 location, as close to the center of each rooftop type as possible. The filters collected were outdoor ventilation 104 air filters only; the duty cycle of the outdoor air ventilation fans was unknown during the filter operational 105 period.

106 2.2. Filter Collection

107 Loaded filters (described as "green" and "white" roof filters hereafter) were collected from AHUs after 108 operation for three-month periods occurring from October 2018 - January 2019 (Fall season) and January 1092019 - March 2019 (Winter season). Samples of filters (area of $17.35 \mathrm{~cm}^{2}$ ) for analysis were randomly cut 110 from an intact filter, using sterilized stainless-steel scissors, from a filter taken from the AHU filter bank. 111 An unused filter of the same make (AAF PerfectPleat, HC M8) was acquired from maintenance personnel 112 immediately after the filter collection period. Filters were immediately sealed and stored in a polyethylene 113 bag at $-15^{\circ} \mathrm{C}$ freezer until tested for DNA composition, ozone removal and VOC emissions.

114 2.3. Filter microbial composition analysis 
The collected HVAC filter samples were cut inside a biological safety cabinet into $10 \mathrm{~cm}^{2}$ pieces $(5 \mathrm{x}$

$1162 \mathrm{~cm}$ ) before being put into individual $5 \mathrm{~mL}$ tubes for biomass removal. For each filter panel, six random

$11710 \mathrm{~cm}^{2}$ pieces from different parts of the panel were cut and analyzed for replication purposes. Biomass is

118 first removed from the filter by washing with $6 \mathrm{~mL}$ phosphate buffer saline (PBS) $+0.1 \% \mathrm{v} / \mathrm{v}$ Triton X-100

119 (non-ionic detergent). The wash buffer containing the biomass is subsequently concentrated on $0.02 \mu \mathrm{m}$ 120 Anodisc (Whatman) using a vacuum manifold (DHI) and immediately subjected to DNA extraction. DNA 121 was extracted with Qiagen DNeasy Power Water kit following the manufacturer's protocol with slight 122 modifications to improve DNA yield. Briefly, during cell lysis step, a $30-\min 65^{\circ} \mathrm{C}$ water bath incubation 123 was added before the recommended 5-min bead-beating step ${ }^{32}$.

After extraction, total DNA concentration was quantified using Qubit 2.0 fluorometer with dsDNA HS 125 (high sensitivity) kit (Invitrogen) and finally presented in ng of DNA per $\mathrm{cm}^{2}$ of filter. Concurrently, 126 Metagenomic sequencing was also performed on the extracted DNA samples with shotgun approach. 127 Accel-NGS 2S Plus DNA kit (Swift Biosciences) was used to create the sequencing libraries. DNA was 128 first sheared with Covaris S220 or E220 focused ultra-sonicator to 450bp size. Dual-barcodes with indices 129 from the 2S Dual indexing kit (Swift Biosciences) were then added to all libraries and validated on the 130 Bioanalyzer DNA 7500 chip (Agilent). Finally, library concentrations were normalized to $4 \mathrm{nM}$ and pooled 131 at equal volume for sequencing on Illumina HiSeq 2500 platform with rapid runs at a final concentration 132 of 10-11 pM and read length of $251 \mathrm{bp}$ paired ends (Illumina HiSeq $2500 \mathrm{~V} 2$ rapid sequencing chemistry).

The resulting raw sequences were first subjected to adapter removal and quality trimming (Phred quality Q20) with Cutadapt v 1.8.133. Trimmed reads were then aligned to NCBI non-redudant (nr) protein database (ver. 22 November 2019) with a maximum of 5 allowed mismatches and e-value cutoff of 0.01 for taxonomic assignment with $\mathrm{Kaiju}^{34}$. The outputs were finally visualized with MEGAN v6.17 $7^{35}$ and the 137 final DNA composition of the filter samples was presented in percentage (\%) of assigned reads at phylum 138 level. All raw sequences used in this study have been uploaded to the National Center for Biotechnology 139 Information (NCBI) Sequence read archives (SRA) under bioproject accession number PRJNA681296. 
Filters were tested for emissions of VOCs in the presence and absence of ozone and ozone removal in

142 the apparatus shown in figure 1. The apparatus uses filtered and humidified compressed air that is injected into a temperature-controlled filter cartridge assembly for VOC emissions and ozone removal measurement.

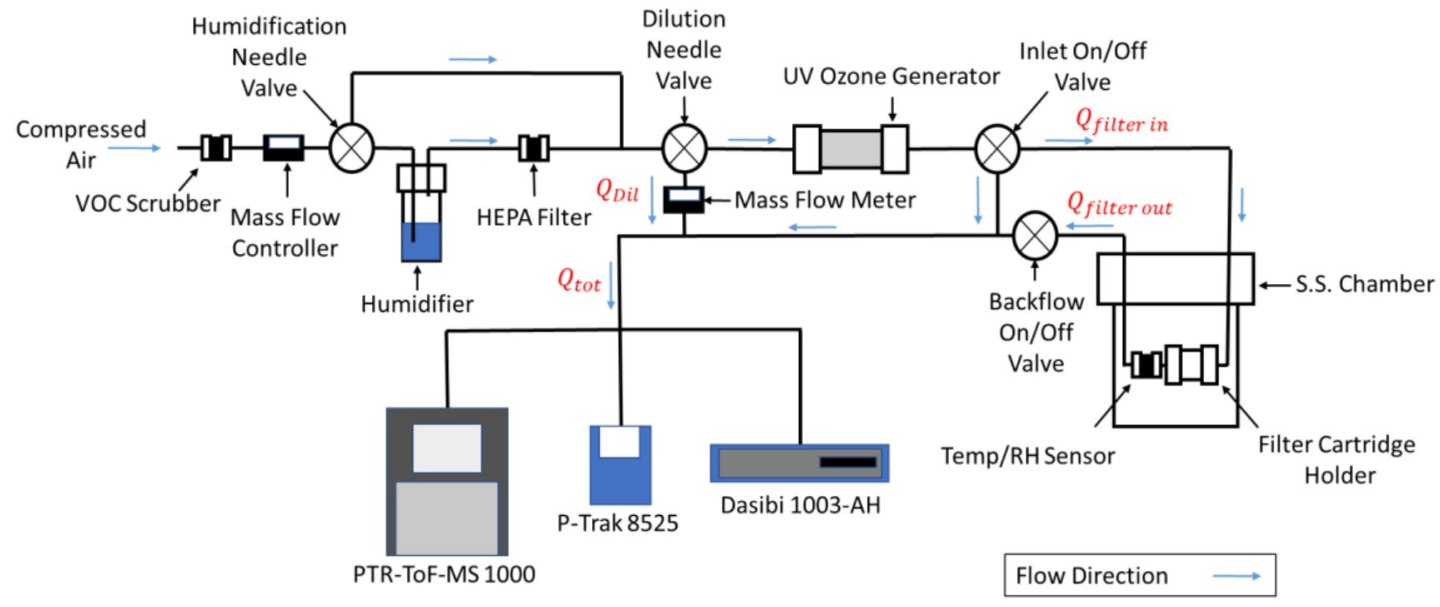

Figure 1. Filter chamber set up for primary emissions, ozone deposition and emissions in the presence of ozone.

The apparatus uses an activated carbon filter (IRAC40, Ingersoll-Rand, Ireland) prior to humidification and a HEPA filter (HC01U-4N-B, ETA Filters, USA) after the humidifier, the latter necessary as we observed an elevated background particle number due to the humidification. Humidification is regulated using a 1000 mL gas-washing cylinder (LG-3765-130, Wilmad Lab Glass, USA) filled with distilled water and a needle valve to control the flow into the humidification cylinder. Ozone generation is controlled using a shortwave (185 nm) UV photochemical ozone generator (SOG-1, AnalytikJena, Germany). A dilution flow is used to provide adequate flow to the instruments, 2 LPM, while maintaining a filter face velocity of $1.1-1.3 \mathrm{~cm} \mathrm{~s}^{-1}$, chosen for consistency with prior bench-scale laboratory analysis ${ }^{10,36}$. Filters are placed in a PFA filter holder (PFA 225-1712, Savilex, USA) inside a temperature controlled stainless steel chamber. A 12-Bit combined temperature and relative humidity (RH) sensor (S-THB-M008, Onset, USA) is used to measure the temperature and $\mathrm{RH}$ of the air. Ozone is measured using a UV ozone analyzer (1003-AH, 
Dasibi, USA). Particle counts $(0.02-1 \mu \mathrm{m})$ are measured using through a P-Trak Ultrafine Particle Counter

159

160

161

162

163

164

165

166

167

168

169

170

171

172

173 174 (m/z 69.07), and monoterpenes (m/z 137.12).

175

176

177

178

179

180

181

(P-Trak Ultrafine Particle Counter 8525, TSI, USA).

\subsection{Experimental protocol}

Primary VOC emissions and VOC emissions in the presence of ozone were measured using a proton transfer reaction - time of flight - mass spectrometry (PTR-TOF-MS 1000, Ionicon, Austria) with $\mathrm{H}_{3} \mathrm{O}^{+}$as the primary reagent ion $\mathrm{O}_{2}{ }^{+}$and $\mathrm{NO}^{+}$signal intensities were respectively less than $5 \%$ and $1 \%$ of $\mathrm{H}_{3}{ }^{18} \mathrm{O}^{+}$ and water cluster $\left(\left(\mathrm{H}_{2} \mathrm{O}\right) \mathrm{H}_{3} \mathrm{O}^{+}\right)$intensities around $1-2 \%$ of $\left.\mathrm{H}_{3}{ }^{18} \mathrm{O}^{+}\right)$. Drift tube conditions were $\mathrm{T}_{\text {drift }}=60^{\circ} \mathrm{C}$, $\mathrm{P}_{\text {drift }}=2.20$ mbar, $\mathrm{U}_{\text {drift }}=600 \mathrm{~V}$, which resulted in electric field strength to number density ratio $\mathrm{E} / \mathrm{N}=135$ Td (Townsend, $\left.1 \mathrm{Td}=10-17 \mathrm{~V} \mathrm{~cm}^{2}\right)$. The mass axis calibration was performed using three peaks: $\mathrm{NO}^{+}(\mathrm{m} / \mathrm{z}$ $=29.9974), \mathrm{C}_{3} \mathrm{H}_{7} \mathrm{O}^{+}(\mathrm{m} / \mathrm{z}=59.0497)$ and a $\mathrm{C}_{6} \mathrm{H}_{4} \mathrm{I}_{2}$ fragment $(\mathrm{m} / \mathrm{z}=203.944)$ via an internal standard continuously injected into the drift tube via a heated permeation device (PerMaScal, Ionicon Analytik $\mathrm{GmbH}$, Innsbruck, Austria). Mass spectra were stored in $30 \mathrm{~s}$ intervals. The inlet was held at $60^{\circ} \mathrm{C}$ and the supplemental inlet flow to the drift tube was set at $150 \mathrm{~mL} \mathrm{~min}{ }^{-1}$.

A peak list of compounds of interest was chosen based on the potential for emissions from biotic matter and precursors for byproduct formation and oxidation byproducts ${ }^{37-46}$. These compounds are shown in table S1 of the supporting information document. Putative IDs of these compounds are: methanol (m/z 33.03), acetaldehyde (m/z 45.03), formic acid (m/z 47.01), acetone (m/z 59.04), acetic acid (m/z 61.03), isoprene

Loaded and unused field filter samples were cut to flat circular samples of diameter of $47 \mathrm{~mm}$ and placed in the filter holder. The filter sample is compressed between two mating PFA surfaces and the operative area exposed to airflow (ozone free or containing ozone) was $17.35 \mathrm{~cm}^{2}$. Prior to each experiment, the filter cartridge is cleaned and passivated at $200 \mathrm{ppb}$ ozone for 12 hours to remove any confounders due to cartridge handling. Three relative humidity and three temperature conditions were tested for the fall season filters: $20 \%, 50 \%$ and $80 \% \mathrm{RH}$ and $15{ }^{\circ} \mathrm{C}, 23^{\circ} \mathrm{C}$ and $31^{\circ} \mathrm{C}$, respectively. Temperatures were chosen 
182 to characterize the behavior of filters across realistic outdoor temperatures. The range was selected to span

$183>10{ }^{\circ} \mathrm{C}$, as a rule of thumb (Arrhenius equation) predicts will lead to a doubling of the reaction rate, while

184 considering limitations of our laboratory setup to maintain elevated and lowered chamber concentrations

185 for the duration of each experiment. High and low temperature and $\mathrm{RH}$ conditions were tested in duplicates

186 for the fall season. The median condition, $50 \% \mathrm{RH}$ and $23{ }^{\circ} \mathrm{C}$, was tested in triplicates for the fall and winter

187 season. A flow rate of 1.2-1.4 $\mathrm{L} \mathrm{min}^{-1}$ of air is sent to the filter cartridge, resulting in a face velocity of 1.1-

$1881.3 \mathrm{~cm} \mathrm{~s}^{-1}$. Measurements were split into two $2.5 \mathrm{~h}$ segments for each filter; the first segment was to measure

189 filter primary VOC emissions and downstream particle concentration and a second segment to measure

190 filter ozone removal efficiencies, secondary organic aerosol formation and VOC emissions in the presence

191 of ozone. For each $2.5 \mathrm{~h}$ segment the inlet concentration was measured for the first $0.5 \mathrm{~h}$, the outlet

192 concentration measured for the next $1.5 \mathrm{~h}$ and finally the inlet concentration was measured again for $0.5 \mathrm{~h}$

193 (figure S2). For the first $2.5 \mathrm{~h}$ segment, $\mathrm{O}_{3}$ levels were $<2 \mathrm{ppb}$ and during the second segment ozone was

194 injected, with filter holder inlet levels ranging 170-190 ppb. Experiments were run in duplicate, except for

195 the median temperature and $\mathrm{RH}$ conditions $\left(23^{\circ} \mathrm{C}\right.$ and $\left.50 \% \mathrm{RH}\right)$ for the fall and winter data set, which was

196 run in triplicate. The averaged concentrations reported here are the time-average of the final 30 minutes of

197 the $1.5 \mathrm{~h}$ outlet measurement. This period met the steady-state conditions for ozone, $<2 \mathrm{ppb}$ change over

19810 mins $^{47}$.

199 3. Theory/Calculation

$200 \quad$ 3.1.1. Volatile organic source and sink strength quantification

201 Primary VOCs were calculated according to the following equation:

202

$203 \overline{F_{\text {fllter }}}=\left[\left[\left(\frac{\overline{\bar{C}_{l, \text { tot out }}} \times Q_{\text {tot }} \text { out }}{Q_{\text {filter out }}-\overline{C_{l, l n}} \times Q_{\text {dil }} \text { out }}-\overline{C_{l, l n}}\right) \times \frac{Q_{\text {filter out }}}{A}\right] \times \alpha\right]-\overline{F_{\text {background }}}$

204 where subscripts 'out' and 'in' represent the flow through the filter chamber and flow bypassing the filter

205 chamber, respectively. The mean primary VOC flux from the filter $\left(\mu \mathrm{mol} \mathrm{m}^{-2} \mathrm{~h}^{-1}\right)$ is $\overline{F_{\text {fllter }}}, \overline{C_{l, \text { tot }} \text { out }}$ is the 
mean total outlet concentration of compound $i(\mathrm{ppb}), Q_{\text {tot }}$ out is the total flow during the respective outlet

207 period $\left(\mathrm{L} \mathrm{min}^{-1}\right), \overline{C_{l, l n}}$ is the mean inlet concentration of compound $i(\mathrm{ppb}), Q_{\text {dil }}$ out is the dilution flow

208 during the outlet measurement period $\left(\mathrm{L} \mathrm{min}^{-1}\right), Q_{\text {filter out }}$ is the flow measurement at the outlet of the filter

$209(\mathrm{~L} \mathrm{~min}-1), A$ is the area of the exposed filter $\left(\mathrm{m}^{2}\right), \alpha$ is the unit conversion factor to convert from units of

$210 \mathrm{ppb} \mathrm{L} \mathrm{m} \mathrm{min}^{-1}$ to units of $\mu \mathrm{mol} \mathrm{m}^{-2} \mathrm{~h}^{-1}$ and depends on the molecular weight of the specific compound,

211 and finally $\overline{F_{\text {background }}}$ is the mean background VOC flux $\left(\mu \mathrm{mol} \mathrm{m} \mathrm{m}^{-2} \mathrm{~h}^{-1}\right)$ in the absence of a filter. Time-

212 averages for $\overline{C_{l, \text { tot }} \text { out }}$ and $\overline{C_{l, l n}}$ were taken over the last 30 minutes of the oulet and inlet period, respectively.

$213 Q_{\text {filter out }}$ was calculated by subtracting $Q_{\text {dil }}$ out from $Q_{\text {tot }}$ out .

214 VOC emissions in the presence of ozone was calculated in a similar manner and shown below:

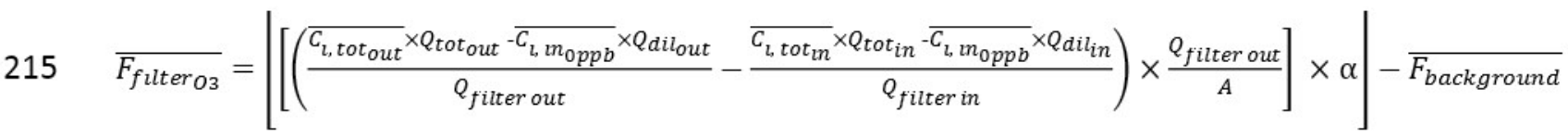

217 where the second part of the right side of the equation represents the potential change in concentration of

218 compound $i(\mathrm{ppb})$ with respect to the increased ozone concentration. $\overline{C_{l, n_{0 p p b}}}$ is the mean inlet 219 concentration of compound $i$ at $0 \mathrm{ppb}$ ozone (ppb), $\overline{C_{l, t_{t n}}}$ is the mean total inlet concentration of 220 compound $i(\mathrm{ppb}), Q_{\text {tot }_{\text {in }}}$ is the total flow during the inlet measurement period $\left(\mathrm{L} \mathrm{min} \mathrm{m}^{-1}\right), Q_{d i l_{\text {in }}}$ is the 221 dilution flow during the respective measurement period (LPM), and $Q_{\text {in }}$ is the ozonated inlet flow ( $\mathrm{L} \mathrm{min}^{-}$

$\left.22{ }^{1}{ }^{1}\right) \cdot Q_{\text {filter in }}$ was measured through bypassing the filter chamber and calculated by subtracting $Q_{\text {dil }}$ from $223 Q_{\text {tot }_{\text {in }}}$ 
$226 \quad \eta=1-\frac{\frac{c_{\text {t tot }_{\text {out }}} \times Q_{\text {tot }_{\text {out }}}}{Q_{\text {filter out }}}}{\frac{c_{\text {, tot }} \times Q_{\text {tot }} \text { in }}{Q_{\text {filterin }}}}$

227 where $\eta$ is removal efficiency (\%), $\overline{C_{l, \text { tot }_{\text {out }}}}$ and $\overline{C_{l, t_{\text {tot }}}}$ are the mean outlet and inlet ozone concentration

228 in (ppb) and the other variables are previously mentioned. Averages for $\overline{C_{l, \text { tot }_{\text {out }}}}$ and $\overline{C_{l, \text { tot }}}$ were taken 229 over the last 30 minutes of the respective experimental period.

\subsubsection{Contribution to ventilation air}

The contribution of filter emissions to ventilation air downstream of the filter is provided by a massbalance on a volume of air passing through the air-handler containing a filter ${ }^{25}$ :

$233 C_{\text {in }}=C_{\text {out }}+\frac{F_{\text {filter }} \times R}{V \times \beta}$

234 where $C_{\text {in }}$ and $C_{\text {out }}$ are inlet $\left(\mu \mathrm{g} \mathrm{m}^{-3}\right)$ and outlet concentrations upstream and downstream a hypothetical 235 filter, respectively, $F_{\text {filter }}$ is the emission flux $\left(\mu \mathrm{g} \mathrm{m}^{-2} \mathrm{~h}^{-1}\right)$ converted from units of $\mu \mathrm{mol} \mathrm{m}^{-2} \mathrm{~h}^{-1}, R$ is the 236 ratio of filter media surface area to filter face area (dimensionless), $V\left(\mathrm{~m} \mathrm{~s}^{-1}\right)$ is the filter face velocity, and $237 \beta$ is the unit conversion factor $\left(3600 \mathrm{~s} \mathrm{~h}^{-1}\right)$. $\mathrm{R}$ values can vary depending on the type of filter; pad filter $238(\mathrm{R}=1)$, pleated filter $(\mathrm{R}=4)$, thick pleated filter $(\mathrm{R}=10)$, and bag filter $(\mathrm{R}=19)$. The contribution of the filter 239 to the indoor concentration is given by $\frac{E \times R}{V}$.

\subsubsection{Statistical analysis and uncertainty propagation} across seasonal, temperature and RH datasets. Shapiro-Wilk tests with output p-value $<0.05$ were ignored

243 from ANOVA tests. A three-way ANOVA considered the effects of season (fall and winter), filter type

244 (green and white), and trial (non-ozonated and ozonated) and associated interactions on compounds from 245 the seasonal dataset that passed the Shapiro-Wilk tests, presented in table S2. Data on unused filters was 246 not included in these analyses, as season is not an independent variable of unused filters. A three-way 
248 unused), and trial and their associated interactions on compounds that passed the Shapiro-Wilk tests for the 249 temperature dataset and shown in table S3. A similar three-way unbalanced ANOVA considered the effects 250 of $\mathrm{RH}(20 \%, 50 \%$ and $80 \% \mathrm{RH})$, filter type (green, white and unused), and trial and associated interactions 251 on compounds that passed the Shapiro-Wilk tests for the RH dataset, presented in table S4. A Tukey 252 multiple comparison post hoc test was employed for all three-way ANOVA tests.

253 A Friedman's test was applied, similar to a one-way ANOVA with repeated measures ${ }^{48,49}$, for filter 254 type (green, white and unused) across the two trial conditions (non-ozonated and ozonated) for the selected 255 compounds that did not pass the Shapiro-Wilk normality tests for the fall season dataset, shown in table 256 S5. A Dunn's pair wise post hoc analysis was performed between the ranks of the Friedman's test and a 257 Bonferroni post hoc correction for multiple tests was applied. A p-value $\leq 0.05$ was deemed a significant 258 difference among the variables tested for each dataset. All statistical tests, analysis and graphs were 259 performed and generated in MATLAB.

260 Uncertainty for VOC fluxes at each condition was estimated by propagating the difference between the 261 maximum and minimum averaged concentrations across replicates for each selected compound. Propagated 262 uncertainty for ozone removal was calculated using $2 \%$ instrumentation error on inlet and outlet 263 concentrations.

\section{4. Results and Discussion}

An illustrative dataset collected from chamber studies is shown in figure 2, with green roof filter data 266 shown for select VOCs, particle number concentrations, and inlet and outlet ozone levels at $23^{\circ} \mathrm{C}$ and $50 \%$

267 RH. Results from the experiments on fall filters studied across all temperature and RH conditions are 268 presented in table S6. VOC fluxes were calculated based on eq. 1 and eq. 2 and normalized to background 269 concentrations. Periods in which the background concentration is higher is due to the filter behaving as a sink and shown as a negative flux in table S6. 


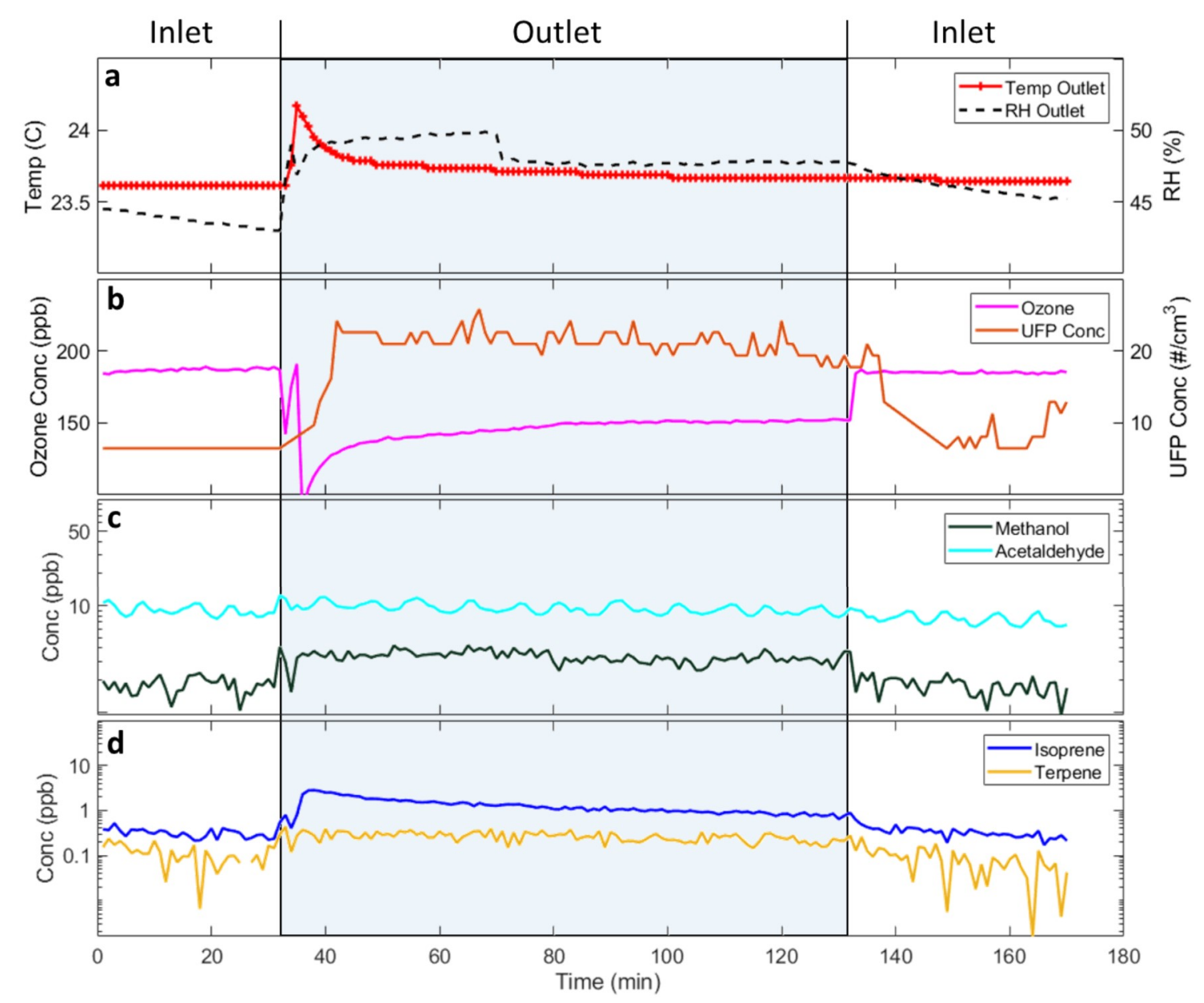

Figure 2. Representative measurements from filter ozonolysis experiment for fall season green roof sample at the $23^{\circ} \mathrm{C}$ and $50 \% \mathrm{RH}$. The inlet concentrations are measured in the first $\sim 30$ mins, then $\sim 90$ mins of outlet concentrations are measured (shaded area) and finally $\sim 40$ mins of inlet concentrations $\mathbf{a}$.

275 Temp (C) and RH (\%) b. Ozone (ppb) and Particle number concentration $\left(\frac{\#}{\mathrm{~cm}^{3}}\right)$ concentration c. Methanol 276 (ppb) and Acetaldehyde (ppb) concentrations d. Isoprene (ppb) and Terpene (ppb) dominated the VOC fluxes that were tracked. Compounds of interest for this study were methanol $\left(\mathrm{CH}_{3} \mathrm{OH}\right)$, acetaldehyde $\left(\mathrm{C}_{2} \mathrm{H}_{4} \mathrm{O}\right)$, formic acid $\left(\mathrm{CH}_{2} \mathrm{O}_{2}\right)$, acetone $\left(\mathrm{C}_{3} \mathrm{H}_{6} \mathrm{O}\right)$, acetic acid $\left(\mathrm{CH}_{3} \mathrm{COOH}\right)$, isoprene $\left(\mathrm{C}_{5} \mathrm{H}_{8}\right)$ and terpenes $\left(\left(\mathrm{C}_{5} \mathrm{H}_{8}\right)_{n}\right)$; emission fluxes are reported in full in table $\mathbf{S 6}$ of supporting information. For the fall season at $23^{\circ} \mathrm{C}$ and $50 \% \mathrm{RH}$, methanol emissions from green and white filters are 
284 similar in magnitude at $10.96 \pm 3.09$ and $12.02 \pm 3.41 \mu \mathrm{mol} \mathrm{m}^{-2} \mathrm{hr}^{-1}$, respectively, and were significantly 285 more emissive than the unused filters which measured $5.64 \pm 1.08 \mu \mathrm{mol} \mathrm{m}^{-2} \mathrm{hr}^{-1}$. Methanol fraction of the 286 total flux of the selected compounds were between $60-100 \%$ for green and white filters after background 287 (empty filter holder) emissions were accounted for. Methanol fluxes from filters may be partially a result 288 of cellulose composition of filters ${ }^{18}$. Cellulose composes many plant and wood walls $\mathrm{s}^{50,51}$ and methanol has 289 been found to be a major component of VOC fluxes from plant and wood material ${ }^{52}$, potentially explaining 290 the high methanol flux in unused filters. Higher fluxes of methanol from green and white roof filters could 291 be due to numerous reasons, including; local plant leaf emissions of methanol being sorbed and desorbed 292 from filters ${ }^{40}$, suspension and entrapment of soil or plant litter, which can include cellulose containing biotic 293 matter, leading to emissions of methanol ${ }^{53,54}$, or anthropogenic sources such as traffic that could emit 294 methanol that is sorbed onto HVAC filters ${ }^{55}$.

Primary fluxes of isoprene and terpenes, which are known precursors for secondary organic aerosol 296 formation, were small across all temperature, $\mathrm{RH}$, and seasonal conditions; $0.07 \pm 0.08$ and $0.01 \pm 0.08$ $297 \mu \mathrm{mol} \mathrm{m} \mathrm{hr}^{-1}$ respectively, relative to other compounds for all filter types. One possible explanation is that 298 since the filters were stored for roughly four months in a polyethylene bag at $-15^{\circ} \mathrm{C}$ freezer, active plant 299 cells trapped on filters may have deteriorated and lost their ability to perform metabolic processes that 300 produce isoprene and terpenes ${ }^{56,57}$. Another potential rationale for the low terpene flux may be due to these 301 compounds being more strongly sorbed to the filter or dissolved in a reservoir where the mass transfer 302 across the boundary of the reservoir is much slower ${ }^{58}$.

303 Methanol fluxes were lower in the presence of ozone, suggesting methanol consumption during 304 ozonolysis and potential for secondary biproducts. Furthermore, isoprene fluxes increased in the presence 305 of ozone for green roof filters, increasing from $0.15 \pm 0.41$ to $0.40 \pm 0.22 \mu \mathrm{mol} \mathrm{m}^{-2} \mathrm{hr}^{-1}$, and for white roof 306 filters, from $0.17 \pm 0.30$ to $0.38 \pm 0.33 \mu \mathrm{mol} \mathrm{m} \mathrm{m}^{-2} \mathrm{hr}^{-1}$. We speculate this may result from a few possibilities 307 including; fragmentation of a compound that may lead to a signal at $\mathrm{m} / \mathrm{z} 69.07$ or breakdowns and responses 308 of organic matter present on the filter due to oxidation processes that lead to increases in gas-phase isoprene 
concentrations. Ozone is known to cause death amongst gram-positive and gram-negative bacteria ${ }^{59}$ and is

310 suggested in the food industry as a disinfecting agent ${ }^{60}$. This bacterial destruction could introduce isoprene

311 in the gas-phase from responses in bacterial metabolic mechanisms ${ }^{61-63}$. Another possibility for isoprene

312 emissions in the presence of ozone could be due to plant cells trapped on loaded filters as some plants are

313 known to emit isoprene as a method of reducing oxidative damage to the plant ${ }^{64}$. Isoprene synthesis has

314 been shown to occur on transgenic tobacco plants to prevent oxidative damage ${ }^{65}$ and leaves themselves

315 have been shown to emit isoprene and nitric oxide (NO) during oxidative stress as a protection mechanism ${ }^{66}$.

316 4.2. Ozone Removal for green, white, and unused filters

Ozone removal across filters varied between $3.5 \% \pm 2.8 \%$ to $14 \% \pm 2.8 \%$ depending on the type of

318 filter, temperature, and RH condition, shown in figure 3. Overall, removal efficiencies were in the range of 319 those previously reported; Abbass et al. ${ }^{10}$ found ozone removal efficiencies for green roof and standard 320 rooftop filters were $5 \% \pm 2.8 \%$ to $14 \% \pm 2.8 \%$ removal at $21^{\circ} \mathrm{C}$ across $30 \%$ and $70 \% \mathrm{RH}$ with an inlet 321 ozone concentration of $120 \mathrm{ppb}$.

322 White and green filter removal efficiencies increased as a function of RH, while the unused filters did 323 not vary across RH (figure 3a). Similarly, unused filters did not vary across temperature conditions (figure 324 3b), maintaining approximately $7 \% \pm 2.8 \%$ to $8 \% \pm 2.8 \%$ removal across all changes in temperature.

Ozone removal to filters increased as a function of increasing $\mathrm{RH}$, shown in figure 3a, but effects of 326 temperature (figure 3b) were within propagated uncertainty. The highest removal was detected at $80 \% \mathrm{RH}$ 327 at $23^{\circ} \mathrm{C}$, which compares well with prior work that reported ozone removal doubles when $\mathrm{RH}$ is increased 328 from $24 \% \mathrm{RH}$ to $80 \% \mathrm{RH}^{67}$. Removal of ozone to filters has been shown to decrease with time $\mathrm{e}^{20,22}$, but, 329 removal efficiencies have been shown to partially recover after filters were treated with clean, non-ozonated 330 air $^{20}$. Figure 3c shows ozone removal efficiencies as a function of season and is discussed in further detail 331 in section 4.4.2. 

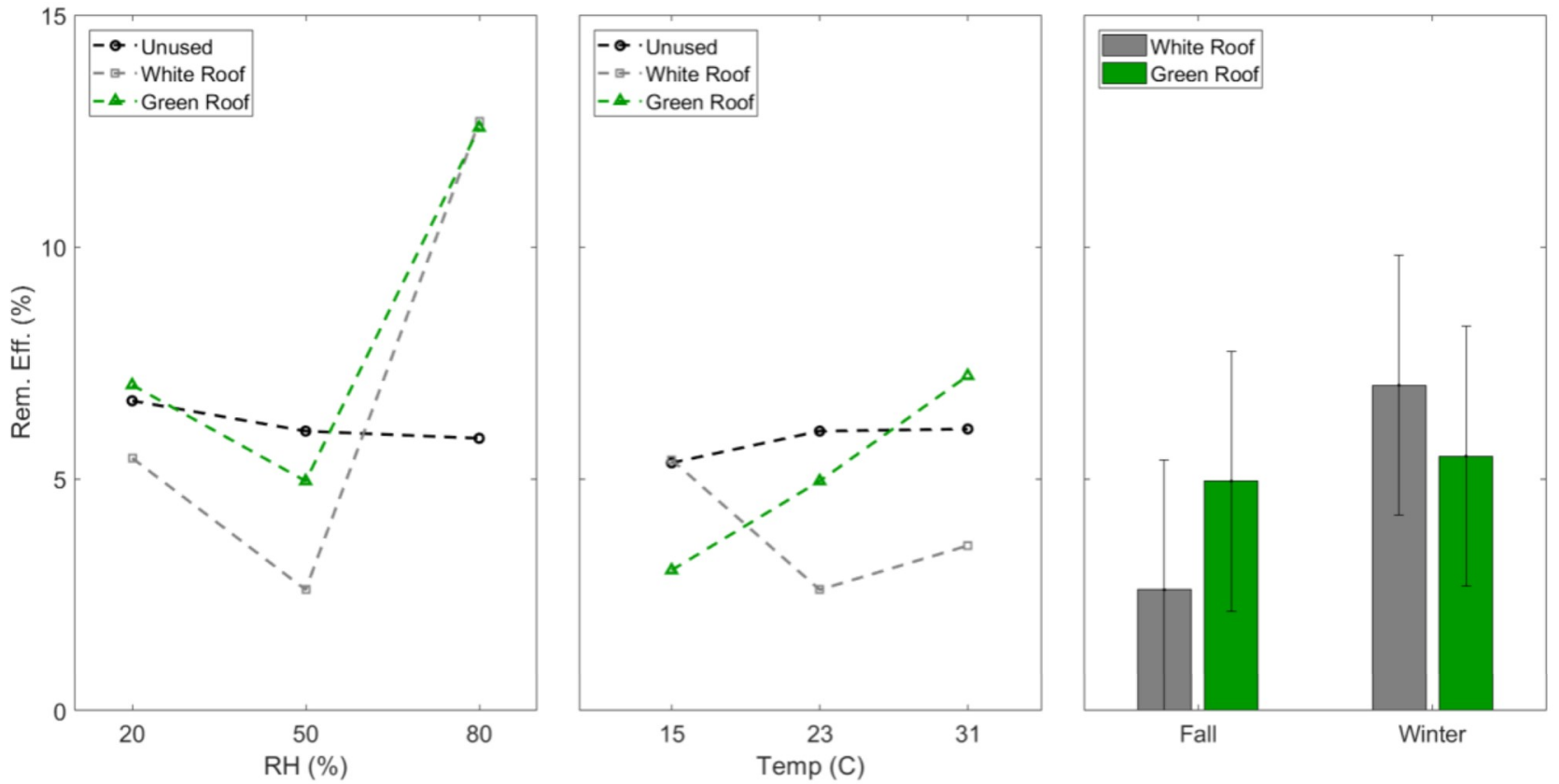

Figure 3. a. Ozone removal efficiency (\%) for fall filters as a function of RH (\%) b. Ozone removal efficiency (\%) for fall filters as a function of Temp (C) c. Ozone removal efficiency (\%) as a function of season (fall and winter). Unsused filters were ignored for the seasonal dataset as seasons have no impact to unused filters. Propagated instrumentation error was calculated to be $\pm 2.8 \%$ removal efficiency for all tests.

\subsection{Microbial characteristics of green and white roof filters}

The microbial characterization of the HVAC filter samples is presented in figure 4 . The green and white roof filters harbor distinct microbial contents in terms of both absolute and relative abundance. Green roof microbial communities change with plant community as well as environmental conditions ${ }^{68}$, and this could explain some of the patterns in filter characteristics observed. The total DNA concentration extracted from the green roof samples was at least double the amount extracted from the white roof samples for both fall and winter samples (figure 4a). Differences in microbial composition between the two filter types are more apparent in winter as compared to fall season with DNA from plant taxa dominating the green roof filters (figure 4b-d). In the fall, both green and white filters were dominated by fungi, especially Ascomycota., which were also the most abundant phyla found in a study of green roof substrates in $\mathrm{NYC}^{68}$. In winter, green roof filters were characterized by plants from Streptophyta, and white roof filters were 
351 and mosses which are common winter active species found on green roofs in Portland ${ }^{69}$. As the filters only 352 processed the ambient outdoor air, this finding reaffirmed how the roof types affected the amount and 353 composition of particles depositing on the HVAC filters.

a

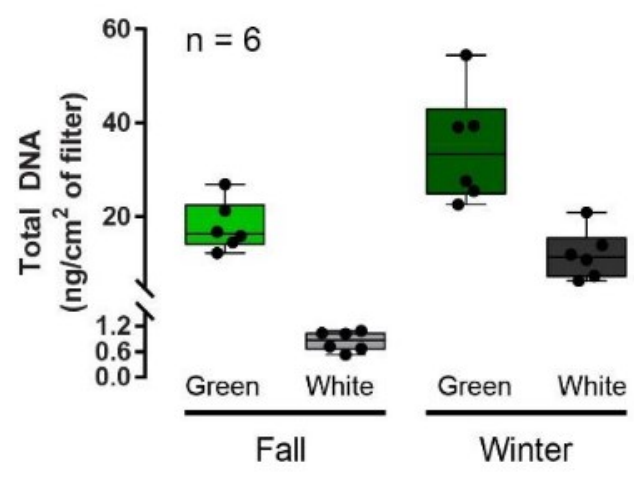

c

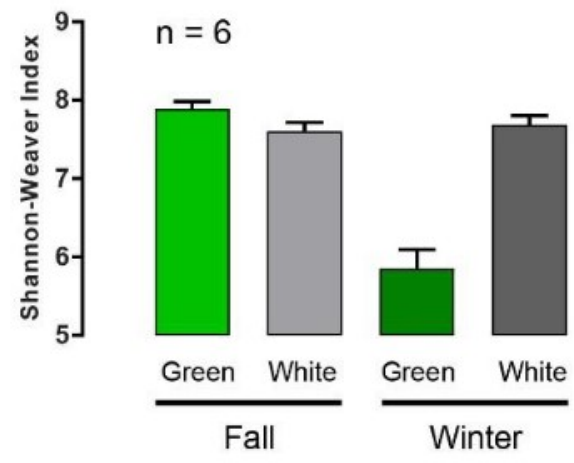

b
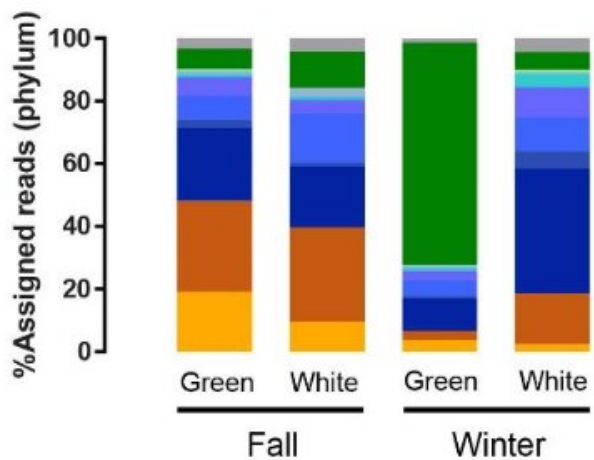

Winter

d

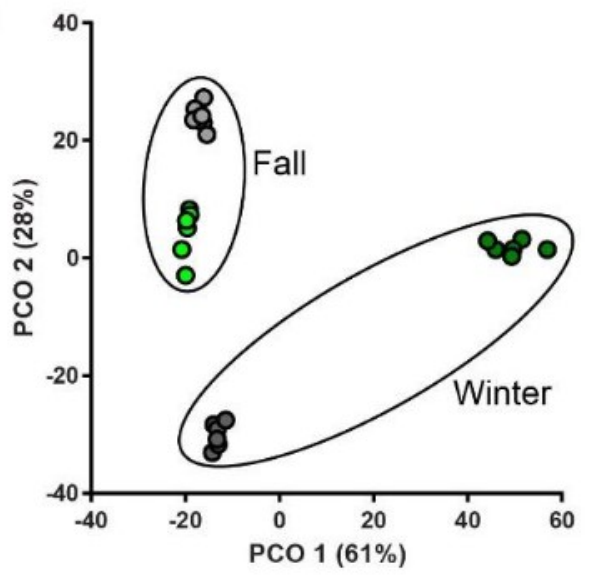

$\mathrm{n}=6$

- Others

Plant

- Streptophyta

Chlorophyta

Bacteria

Firmicutes

Cyanobacteria

Bacteroidetes

Actinobacteria

Acidobacteria

- Proteobacteria

Fungi

- Ascomycota

Basidiomycota

$\square$ Green Fall

$\square$ White Fall

Green Winter

$\square$ White Winter
354

Figure 4. Microbial characteristics of the HVAC filters from green roof (green) and white roof (grey) buildings collected during fall (lighter shade) and winter (darker shade) a. Total DNA concentration per $\mathrm{cm}^{2}$ area of filter $\mathbf{b}$. Microbial composition in percentage of assigned reads on phylum level $\mathbf{c}$. ShannonWeaver diversity index d. Principal coordinates analysis (PCO) based on BrayCurtis similarity matrix. The error bars represent standard deviation with 6 replicates each per filter category.

\subsection{Seasonal variation across green roof and white roof filters}

\subsubsection{VOC emissions across winter and fall seasons}

Primary fluxes for selected compounds were higher in the fall relative to winter seasons. Primary fluxes of methanol at $23^{\circ} \mathrm{C}$ and $50 \% \mathrm{RH}$ were higher for fall season filters, $11.49 \pm 0.40 \mu \mathrm{mol} \mathrm{m}^{-2} \mathrm{hr}^{-1}$, compared to winter filters, $4.35 \pm 0.85 \mu \mathrm{mol} \mathrm{m}^{-2} \mathrm{hr}^{-1}$, and shown in figure 5a. In comparison to the microbial analysis, 
365 fall season had a greater fungal DNA fraction, and this difference may explain the higher methanol fluxes

366 for the fall season filters as fungal degradation of plant cell walls have been shown to form methanol ${ }^{70}$.

367 Primary fluxes of acetaldehyde, formic acid, acetone, and acetic acid were low in magnitude across both

368 fall and winter periods.

369 Fluxes in the presence of ozone exhibited similar seasonal behavior as primary fluxes; higher fluxes of 370 methanol for fall season filters, $3.99 \pm 1.26 \mu \mathrm{mol} \mathrm{m}^{-2} \mathrm{hr}^{-1}$ in relation to the winter filters, $1.74 \pm 0.50 \mu \mathrm{mol}$ $371 \mathrm{~m}^{-2} \mathrm{hr}^{-1}$. Higher fluxes of acetaldehyde, an established byproduct of ozonolysis ${ }^{71-74}$; was also found in the 372 fall season filters, $1.29 \pm 0.94 \mu \mathrm{mol} \mathrm{m}^{-2} \mathrm{hr}^{-1}$ versus winter filters, $1.08 \pm 0.57 \mu \mathrm{mol} \mathrm{m}^{-2} \mathrm{hr}^{-1}$, shown in figure

373 5b. Formic acid, another byproduct of ozonolysis ${ }^{71-74}$, had similar behavior however the differences were 374 within propagated uncertainty. Higher fluxes of methanol and acetaldehyde were found on the fall season 375 green roof sample compared to all other filter samples. Total VOC fluxes of the selected compounds were 376 lower in the presence of ozone but increases in acetaldehyde and formic acid fluxes can have detrimental 377 effects to human health and function ${ }^{75,76}$. There is also potential for increases in fluxes of compounds not 378 tracked in this study. 

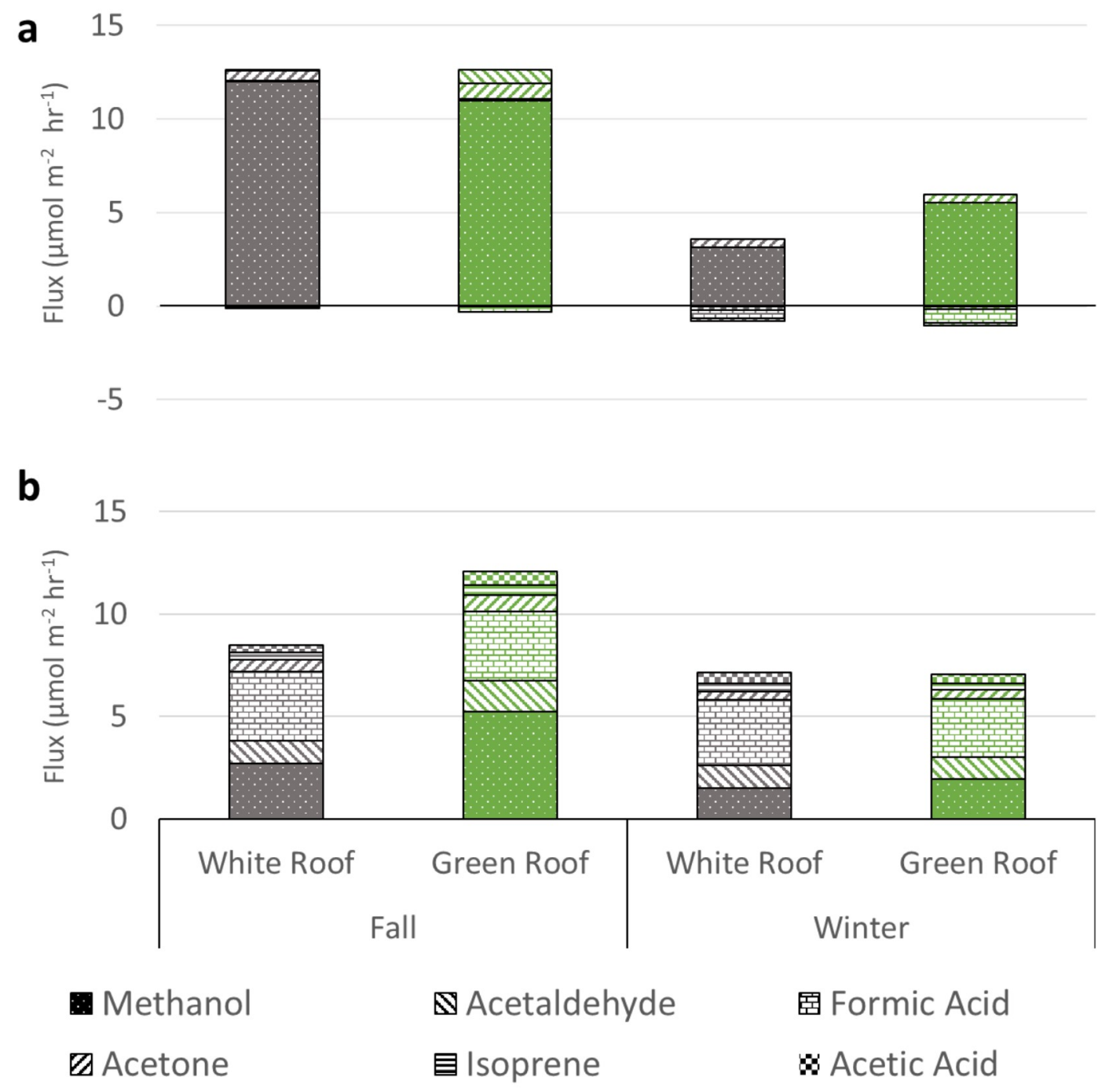

Figure 5. a. Averaged white roof and green roof primary VOC fluxes for selected compounds across seasons at $23^{\circ} \mathrm{C}$ and $50 \% \mathrm{RH} \mathrm{b}$. Averaged white roof and green roof VOC fluxes in the presence of ozone for selected compounds across seasons at $23^{\circ} \mathrm{C}$ and $50 \% \mathrm{RH}$

4.4.2. Ozone removal across winter and fall seasons and $8.0 \% \pm 2.8 \%$ respectively, than those for the fall season, $5.9 \% \pm 2.8 \%$ and $3.6 \% \pm 2.8 \%$ respectively, though the differences were within propagated uncertainty, shown in figure 3c. Green roof filters had 387 similar removal efficiency across the two seasons, but the differences again fell within propagated uncertainty. 


\subsubsection{Microbial variation across winter and fall seasons}

Across both fall and winters seasons, more biomass deposited on the green roof filters than the white 391 roof filters. The DNA concentration difference was substantially higher in fall season (avg. 21-fold) 392 compared to winter season (avg. 3-fold) (figure 4a). In contrast, the relative composition of the loaded 393 matter on the filter were more distinct in winter season between the two roof types. The relative abundances 394 of the top phyla (figure 4b), the diversity index (figure 4c) and the PCO analysis (figure 4d) indicated that 395 while the biomass compositions of the two roof types were similar in fall season, they were significantly 396 different in winter. Taxa originated from plants dominated the green roof filters in winter. On average, the 397 proportion of fungal taxa was higher during fall season than winter season for both types of filters. This result suggests that environmental conditions (e.g. temperature, $\mathrm{RH}$ ) associated with different seasons also, directly or indirectly, impacted particle deposition on the HVAC filters.

Fluxes for the selected compounds varied highly between filter samples for each temperature and $\mathrm{RH}$ condition and shown in table S2. Temperature was not a statistically significant indicator of VOC fluxes of the selected compounds that passed the Shapiro-Wilks test criteria. $\mathrm{RH}$ was found to be a statistically 404 significant indicator of filter fluxes of formic acid, acetone, and isoprene. Further statistical analysis on 405 filter VOC fluxes as a function of temperature and $\mathrm{RH}$ could not be performed due to the non-normality of 406 the dataset. The green roof filter generally had higher total VOC flux of the selected compounds, with the 407 white roof having higher total VOC flux under high RH conditions.

The aerosol number formation (ANF) yield was calculated based on equation 4 present in Wang and 410 Waring $^{29}$ and the average ANF amongst the green, white, and unused filters across all temperature and $\mathrm{RH}$ 411 conditions was, $0.2 \pm 1.7 \frac{\#}{\mathrm{~cm}^{3}} / \frac{\mu \mathrm{g}}{\mathrm{m}^{3}}$, with the green roof sample at $23^{\circ} \mathrm{C}$ and $50 \% \mathrm{RH}$ being the highest at $4120.64 \pm 1.2 \frac{\#}{\mathrm{~cm}^{3}} / \frac{\mu \mathrm{g}}{\mathrm{m}^{3}}$. For comparison, Waring and Seigel found ANF due to surface reactions and gas phase 
413 reactions with d-Limonene was 126-339 $\frac{\#}{\mathrm{~cm}^{3}} / \frac{\mu \mathrm{g}}{\mathrm{m}^{3}}$ and 51.1-60.2 $\frac{\#}{\mathrm{~cm}^{3}} / \frac{\mu \mathrm{g}}{\mathrm{m}^{3}}{ }^{30}$ and Wang and Waring found

414 ANF varied around $2 \frac{\#}{\mathrm{~cm}^{3}} / \frac{\mu g}{\mathrm{~m}^{3}}$ for ozone reactions with surface-sorbed squalene ${ }^{29}$. Low aerosol number

415 fractions are expected given observation of low concentrations of reactive organics (isoprene and 416 monoterpenes) emitted from filters; we speculate that this implies there exist low concentrations of surface-

417 sorbed monoterpenes on tested filter. For comparison, Waring and Seigel, in a study of the role of surfaces

418 to impact SOA formation from oxidation of d-limonene performed experiments with gas-phase

419 concentrations between 400 and $600 \mathrm{ppb},{ }^{30}$ whereas average concentrations of monoterpenes downstream

420 loaded and unloaded filter samples varied between 0.2 and $1 \mathrm{ppb}$ in this study.

421 A thorough study of filter surface properties was not conducted but may be warranted to better 422 understand the fundamental roles of the surface sorbed compounds to the gas-phase filter emissions. Surface 423 environmental scanning electron microscope (ESEM) images and solvent extraction methods are potential 424 ways to better understand the surface properties ${ }^{10,77}$ and chemical composition of filter loaded mass, lending 425 further mechanistic insight into what conditions may yield secondary aerosol formation from surface 426 ozonolysis of filters. Future studies could also consider testing filters in-situ, e.g., by generating ozone on427 site or immediately after sampling from the field; it is possible that volatile reactive organics were lost in 428 our sample handling and storage.

429 4.7. VOC contribution to the indoor environment

430 Results of the estimate of the impact of primary emission of VOCs from filters on ventilation air quality 431 (i.e., air downstream a hypothetical filter, emitting at rate measured in this study) is made using equation 432 4. A median face velocity, $0.5 \mathrm{~m} \mathrm{~s}^{-1}$ was chosen to represent typical flow rates for a $1 \mathrm{~m}^{2}$ filter area ${ }^{25}$, and 433 a high and low value of $1 \mathrm{~m} \mathrm{~s}^{-1}$ and $0.1 \mathrm{~m} \mathrm{~s}^{-1}$ was chosen to represent high and low HVAC air flow conditions 434 respectively. Low face velocities are on the order of $360 \mathrm{~m}^{3} \mathrm{~h}^{-1} /\left(\mathrm{m}^{2}\right.$ filter area) and high face velocities are 435 approximately $3600 \mathrm{~m}^{3} \mathrm{~h}^{-1} /\left(\mathrm{m}^{2}\right.$ filter area $)$. Steady-state contribution to indoor ventilation air for five VOCs 436 for green and white roof filters at various face velocities and ' $\mathrm{R}$ ' values are given in table S7. 
438 face velocities is shown in figure 6. For loaded green roof bag filters $(R=19)$ operating at low flow rates, 439 the steady-state contribution to the indoor ventilation air is approximately $19 \pm 0.5 \mu \mathrm{g} \mathrm{m}^{-3}$ which can be a 440 substantial contribution to the indoor environment given that a typical range of indoor air methanol 441 concentrations is $10-30 \mu \mathrm{g} \mathrm{m}^{-3} 78$.

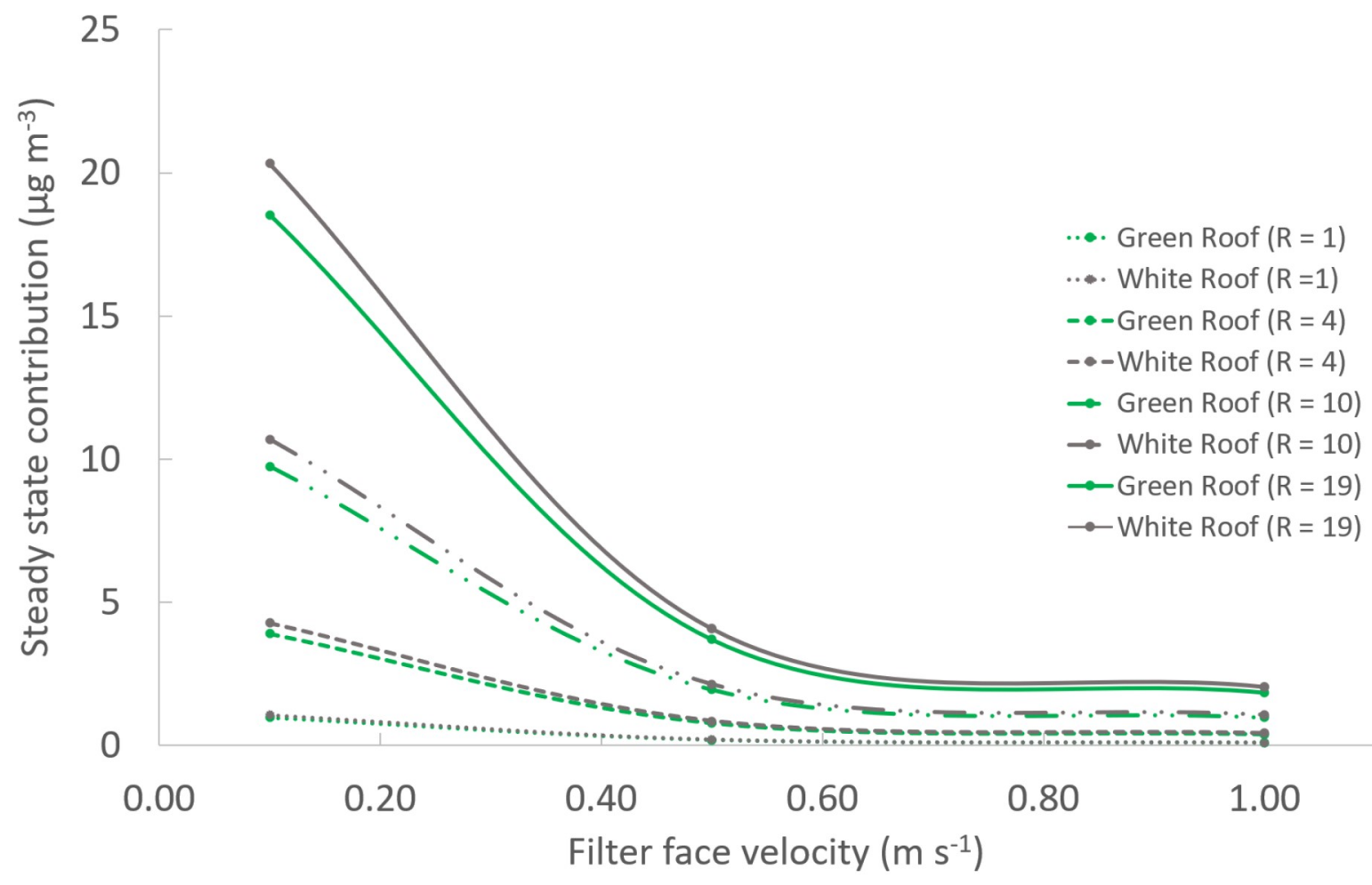

443

444
Figure 6. Steady state volatile contribution to the indoor environment for green (GR) and white (WR) roof filters for different filter types; pad filter $(R=1)$, thick pleated filter $(R=7)$, and bag filter $(R=19)$.

For green roof filters from the fall season at $23^{\circ} \mathrm{C}$ and $50 \% \mathrm{RH}$, the measured methanol primary flux was $10.96 \pm 3.09 \mu \mathrm{mol} \mathrm{m} \mathrm{m}^{-2} \mathrm{~h}^{-1}$ and the respective contribution to the indoor ventilation air is $3.90 \pm 0.27$, $0.78 \pm 0.05$, and $0.39 \pm 0.03 \mu \mathrm{g} \mathrm{m}^{-3}$ for the low, medium, and high face velocities and pleated filters $(\mathrm{R}=$ 4). Similarly, for a fall green roof filter at the same temperature and RH conditions and in the presence of $\sim 180 \mathrm{ppb}$ ozone, the measured flux of formic acid is $3.47 \pm 0.78 \mu \mathrm{mol} \mathrm{m}^{-2} \mathrm{~h}^{-1}$ and the contribution to indoor ventilation air is $1.72 \pm 0.38,0.34 \pm 0.08$, and $0.17 \pm 0.04 \mu \mathrm{g} \mathrm{m}^{-3}$ for pleated filters at low, medium, and 
451 high face velocities, respectively. For thick bag filters $(\mathrm{R}=19)$, the contribution to the ventilation air can

452 be sizeable, $3.48 \pm 1.32 \mu \mathrm{g} \mathrm{m}^{-3}$, relative to measured formic acid concentrations in the indoor environment, 453 approximately $9 \mu \mathrm{g} \mathrm{m}^{-3} 79$.

\section{$454 \quad$ 4.8. Conclusions}

In sum, these results show that contributions of loaded filters to the indoor environment can elevate

456 VOC levels in ventilation air and depend on the filter face velocity and the ratio of filter media to face area.

457 Filter VOC fluxes can vary across seasons and potentially vary due to local rooftop environment. Fluxes of 458 methanol overshadowed the compounds tracked in this study, including in unused filters suggesting high 459 methanol fluxes are intrinsic to some HVAC filters. Variation of VOC fluxes of other selected compounds 460 between filter samples made it difficult to assess trends due to temperature, RH, or seasonal conditions. 461 Green and white roof filters collected different microbial contents in terms of both absolute and relative 462 abundance suggesting roof type may affect the amount and composition of biotic particles depositing on 463 the HVAC filters. No particle formation was observed due to surface ozonolysis across varying 464 temperature, RH, and seasonal conditions. Further studies should quantitively characterize the amount and 465 chemical composition of accumulated mass loaded on the filter. These data would contribute to a more 466 complete understanding of the drivers of emissions and chemistry occurring on loaded HVAC filters that 467 may lead to the gas-phase emissions to indoor ventilation air.

469 Acknowledgements

470 This material is based upon work supported by the National Science Foundation under Grant No. 1605843 471 and 1356679. Any opinions, findings, and conclusions or recommendations expressed in this material are 472 those of the author(s) and do not necessarily reflect the views of the National Science Foundation.

473 Funding for metagenomic processing, analyses and interpretation were provided by the SCELSE through 474 Singapore Ministry of Education funding grant MOE2013-T3-1-013. 
475 We would like to thank Aurélie Laguerre and Finnegan Clark for their assistance with this project. 
5. References

477 (1) Shafique, M.; Kim, R.; Rafiq, M. Green Roof Benefits, Opportunities and Challenges - A Review. Renewable and Sustainable Energy Reviews 2018, 90, 757-773.

479

480 https://doi.org/10.1016/j.rser.2018.04.006.

(2) Sailor, D. J.; Elley, T. B.; Gibson, M. Exploring the Building Energy Impacts of Green Roof Design Decisions - a Modeling Study of Buildings in Four Distinct Climates. Journal of Building Physics 2012, 35 (4), 372-391. https://doi.org/10.1177/1744259111420076.

(3) Clark, C.; Adriaens, P.; Talbot, F. B. Green Roof Valuation: A Probabilistic Economic Analysis of Environmental Benefits. Environ. Sci. Technol. 2008, 42 (6), 2155-2161. https://doi.org/10.1021/es0706652.

(4) Oberndorfer, E.; Lundholm, J.; Bass, B.; Coffman, R. R.; Doshi, H.; Dunnett, N.; Gaffin, S.; Köhler, M.; Liu, K. K. Y.; Rowe, B. Green Roofs as Urban Ecosystems: Ecological Structures, Functions, and Services. BioScience 2007, 57 (10), 823-833. https://doi.org/10.1641/B571005.

(5) Bousselot, J.; Russell, V.; Tolderlund, L.; Celik, S.; Retzlaff, B.; Morgan, S.; Buffam, I.; Coffman, R.; Williams, J.; Mitchell, M. E.; DeSpain, J. Green Roof Research in North America: A Recent History and Future Strategies. 38.

(6) Currie, B. A.; Bass, B. Estimates of Air Pollution Mitigation with Green Plants and Green Roofs Using the UFORE Model. Urban Ecosyst 2008, 11 (4), 409-422. https://doi.org/10.1007/s11252008-0054-y.

(7) Jeanjean, A. P. R.; Monks, P. S.; Leigh, R. J. Modelling the Effectiveness of Urban Trees and Grass on PM2.5 Reduction via Dispersion and Deposition at a City Scale. Atmospheric Environment 2016, 147, 1-10. https://doi.org/10.1016/j.atmosenv.2016.09.033.

(8) Ramasubramanian, P.; Starry, O.; Rosenstiel, T.; Gall, E. T. Pilot Study on the Impact of Green Roofs on Ozone Levels near Building Ventilation Air Supply. Building and Environment 2019, 151, 43-53. https://doi.org/10.1016/j.buildenv.2019.01.023.

(9) Xing, Y.; Brimblecombe, P. Role of Vegetation in Deposition and Dispersion of Air Pollution in Urban Parks. Atmospheric Environment 2019, 201, 73-83. https://doi.org/10.1016/j.atmosenv.2018.12.027.

(10) Abbass, O. A.; Sailor, D. J.; Gall, E. T. Ozone Removal Efficiency and Surface Analysis of Green and White Roof HVAC Filters. Building and Environment 2018, 136, 118-127. https://doi.org/10.1016/j.buildenv.2018.03.042.

(11) Batterman, S. A.; Burge, H. HVAC Systems As Emission Sources Affecting Indoor Air Quality: A Critical Review. HVAC\&R Research 1995, 1 (1), 61-78.

https://doi.org/10.1080/10789669.1995.10391309.

(12) Bernstein, R. S.; Sorenson, W. G.; Garabrant, D.; Reaux, C.; Treitman, R. D. Exposures to Respirable, AirbornePenicillium from a Contaminated Ventilation System: Clinical, Environmental and Epidemiological Aspects. American Industrial Hygiene Association Journal 1983, 44 (3), 161169. https://doi.org/10.1080/15298668391404581.

(13) Tang, W.; Kuehn, T. H.; Simcik, M. F. Effects of Temperature, Humidity and Air Flow on Fungal Growth Rate on Loaded Ventilation Filters. Journal of Occupational and Environmental Hygiene 2015, 12 (8), 525-537. https://doi.org/10.1080/15459624.2015.1019076.

(14) Ahearn, D. G. Fungal Colonization of Air Filters and Insulation in a Multi-Story Office Building: Production of Volatile Organics. Current Microbiology 1997, 35 (5), 305-308. https://doi.org/10.1007/s002849900259.

(15) Weschler, C. J. Indoor/Outdoor Connections Exemplified by Processes That Depend on an Organic Compound's Saturation Vapor Pressure. Atmospheric Environment 2003, 37 (39-40), 5455-5465. https://doi.org/10.1016/j.atmosenv.2003.09.022. 
(16) Hyttinen, M.; Pasanen, P.; Kalliokoski, P. Adsorption and Desorption of Selected VOCs in Dust Collected on Air Filters. Atmospheric Environment 2001, 35 (33), 5709-5716. https://doi.org/10.1016/S1352-2310(01)00376-4.

(17) Hyttinen, M.; Pasanen, P.; Björkroth, M.; Kalliokoski, P. Odors and Volatile Organic Compounds Released from Ventilation Filters. Atmospheric Environment 2007, 41 (19), 4029-4039. https://doi.org/10.1016/j.atmosenv.2007.01.029.

(18) Schleibinger, H.; Ruden, H. Air Filters from HVAC Systems as Possible Source of Volatile Organic Compounds (VOC) - Laboratory and Field Assays. Atmospheric Environment 1999, 7.

(19) Bekö, G.; Clausen, G.; Weschler, C. J. Further Studies of Oxidation Processes on Filter Surfaces: Evidence for Oxidation Products and the Influence of Time in Service. Atmospheric Environment 2007, 41 (25), 5202-5212. https://doi.org/10.1016/j.atmosenv.2006.07.063.

(20) Beko, G.; Halas, O.; Clausen, G.; Weschler, C. J. Initial Studies of Oxidation Processes on Filter Surfaces and Their Impact on Perceived Air Quality. Indoor Air 2006, 16 (1), 56-64. https://doi.org/10.1111/j.1600-0668.2005.00401.x.

(21) Zhao, P.; Siegel, J. A.; Corsi, R. L. Ozone Removal by HVAC Filters. Atmospheric Environment 2007, 41 (15), 3151-3160. https://doi.org/10.1016/j.atmosenv.2006.06.059.

(22) Hyttinen, M.; Pasanen, P.; Kalliokoski, P. Removal of Ozone on Clean, Dusty and Sooty Supply Air Filters. Atmospheric Environment 2006, 40 (2), 315-325. https://doi.org/10.1016/j.atmosenv.2005.09.040.

(23) Zhao, P.; Siegel, J.; Corsi, R. Ozone Removal by Residential HVAC Filters. Indoor Air 2005, 5.

(24) Lin, C.-C.; Chen, H.-Y. Impact of HVAC Filter on Indoor Air Quality in Terms of Ozone Removal and Carbonyls Generation. Atmospheric Environment 2014, 89, 29-34.

https://doi.org/10.1016/j.atmosenv.2014.02.020.

(25) Destaillats, H.; Chen, W.; Apte, M. G.; Li, N.; Spears, M.; Almosni, J.; Brunner, G.; Zhang, J. (Jensen); Fisk, W. J. Secondary Pollutants from Ozone Reactions with Ventilation Filters and Degradation of Filter Media Additives. Atmospheric Environment 2011, 45 (21), 3561-3568. https://doi.org/10.1016/j.atmosenv.2011.03.066.

(26) Sidheswaran, M.; Chen, W.; Miller, R.; Cohn, S.; Kumagai, K.; Destaillats, H. Formaldehyde Emissions from Ventilation Filter Under Different Relative Humidity Conditions. 2013, 27.

(27) Evans, R. C.; Tingey, D. T.; Gumpertz, M. L.; Burns, W. F. Estimates of Isoprene and Monoterpene Emission Rates in Plants. Botanical Gazette 1982, 143 (3), 304-310. https://doi.org/10.1086/botanicalgazette.143.3.2474826.

(28) Singh, B.; Sharma, R. A. Plant Terpenes: Defense Responses, Phylogenetic Analysis, Regulation and Clinical Applications. 3 Biotech 2015, 5 (2), 129-151. https://doi.org/10.1007/s13205-0140220-2.

(29) Wang, C.; Waring, M. S. Secondary Organic Aerosol Formation Initiated from Reactions between Ozone and Surface-Sorbed Squalene. Atmospheric Environment 2014, 84, 222-229. https://doi.org/10.1016/j.atmosenv.2013.11.009.

(30) Waring, M. S.; Siegel, J. A. Indoor Secondary Organic Aerosol Formation Initiated from Reactions between Ozone and Surface-Sorbed D -Limonene. Environ. Sci. Technol. 2013, 47 (12), 63416348. https://doi.org/10.1021/es400846d.

(31) Carslaw, N.; Ashmore, M.; Terry, A. C.; Carslaw, D. C. Crucial Role for Outdoor Chemistry in Ultrafine Particle Formation in Modern Office Buildings. Environ. Sci. Technol. 2015, 8.

(32) Luhung, I.; Wu, Y.; Ng, C. K.; Miller, D.; Cao, B.; Chang, V. W.-C. Protocol Improvements for Low Concentration DNA-Based Bioaerosol Sampling and Analysis. PLOS ONE 2015, 18.

(33) Martin, M. Cutadapt Removes Adapter Sequences from High-Throughput Sequencing Reads. 3.

(34) Menzel, P. Fast and Sensitive Taxonomic Classification for Metagenomics with Kaiju. NATURE COMMUNICATIONS 10. 
(35) Huson, D. H.; Auch, A. F.; Qi, J.; Schuster, S. C. MEGAN Analysis of Metagenomic Data. 11.

(36) Destaillats, H. Secondary Pollutants from Ozone Reactions with Ventilation Filters and Degradation of Filter Media Additives. Atmospheric Environment 2011, 8.

Potard, K.; Monard, C.; Le Garrec, J.-L.; Caudal, J.-P.; Le Bris, N.; Binet, F. Organic Amendment Practices as Possible Drivers of Biogenic Volatile Organic Compounds Emitted by Soils in Agrosystems. Agriculture, Ecosystems \& Environment 2017, 250, 25-36. https://doi.org/10.1016/j.agee.2017.09.007. Organic Compounds. International Journal of Mass Spectrometry 2007, 262 (3), 203-210. https://doi.org/10.1016/j.ijms.2006.11.010.

(39) Abis, L.; Loubet, B.; Ciuraru, R.; Lafouge, F.; Dequiedt, S.; Houot, S.; Maron, P. A.; BourgeteauWaste Products. Science of The Total Environment 2018, 636, 1333-1343. https://doi.org/10.1016/j.scitotenv.2018.04.232.

(40) Nemecek-Marshall, M.; MacDonald, R. C.; Franzen, J. J.; Wojciechowski, C. L.; Fall, R. Methanol Emission from Leaves (Enzymatic Detection of Gas-Phase Methanol and Relation of Methanol Fluxes to Stomatal Conductance and Leaf Development). Plant Physiol. 1995, 108 (4), 1359-1368. https://doi.org/10.1104/pp.108.4.1359.

(41) Greenberg, J. P.; Asensio, D.; Turnipseed, A.; Guenther, A. B.; Karl, T.; Gochis, D. Contribution of Leaf and Needle Litter to Whole Ecosystem BVOC Fluxes. Atmospheric Environment 2012, 10.

(42) Kim, S.; Karl, T.; Guenther, A.; Tyndall, G.; Orlando, J.; Harley, P.; Rasmussen, R.; Apel, E. Emissions and Ambient Distributions of Biogenic Volatile Organic Compounds (BVOC) in a Ponderosa Pine Ecosystem: Interpretation of PTR-MS Mass Spectra. Atmos. Chem. Phys. 2010, 10 (4), 1759-1771. https://doi.org/10.5194/acp-10-1759-2010.

(43) Laothawornkitkul, J.; Taylor, J. E.; Paul, N. D.; Hewitt, C. N. Biogenic Volatile Organic Compounds in the Earth System. New Phytologist 2009, 183 (1), 27-51. https://doi.org/10.1111/j.14698137.2009.02859.x.

(44) Bourtsoukidis, E.; Bonn, B.; Noe, S. M. On-Line Field Measurements of BVOC Emissions from Norway Spruce (Picea Abies) at the Hemiboreal SMEAR-Estonia Site under Autumn Conditions. 19, 15.

(45) Bamberger, I.; Hörtnagl, L.; Schnitzhofer, R.; Graus, M.; Ruuskanen, T. M.; Müller, M.; Dunkl, J.; Wohlfahrt, G.; Hansel, A. BVOC Fluxes above Mountain Grassland. Biogeosciences 2010, 7 (5), 1413-1424. https://doi.org/10.5194/bg-7-1413-2010.

(46) Sanhueza, E.; Andreae, M. O. Emission of Formic and Acetic Acids from Tropical Savanna Soils. Geophys. Res. Lett. 1991, 18 (9), 1707-1710. https://doi.org/10.1029/91GL01565.

(47) Coleman, B. K.; Destaillats, H.; Hodgson, A. T.; Nazaroff, W. W. Ozone Consumption and Volatile Byproduct Formation from Surface Reactions with Aircraft Cabin Materials and Clothing Fabrics. Atmospheric Environment 2008, 42 (4), 642-654. https://doi.org/10.1016/j.atmosenv.2007.10.001.

(48) Friedman, M. The Use of Ranks to Avoid the Assumption of Normality Implicit in the Analysis of Variance. null 1937, 32 (200), 675-701. https://doi.org/10.1080/01621459.1937.10503522.

(49) Gabdrashova, R.; Nurzhan, S.; Naseri, M.; Bekezhankyzy, Z.; Gimnkhan, A.; Malekipirbazari, M.; Tabesh, M.; Khanbabaie, R.; Crape, B.; Buonanno, G.; Hopke, P. K.; Amouei Torkmahalleh, A.; Amouei Torkmahalleh, M. The Impact on Heart Rate and Blood Pressure Following Exposure to Ultrafine Particles from Cooking Using an Electric Stove. Science of The Total Environment 2021, 750, 141334. https://doi.org/10.1016/j.scitotenv.2020.141334.

(50) Cosgrove, D. J. Growth of the Plant Cell Wall. Nat Rev Mol Cell Biol 2005, 6 (11), 850-861. https://doi.org/10.1038/nrm1746. 
(51) Mellerowicz, E.; Sundberg, B. Wood Cell Walls: Biosynthesis, Developmental Dynamics and Their Implications for Wood Properties. Current Opinion in Plant Biology 2008, 11 (3), 293-300. https://doi.org/10.1016/j.pbi.2008.03.003.

(52) Risholm-Sundman, M.; Lundgren, M.; Vestin, E.; Herder, P. Emissions of Acetic Acid and Other Volatile Organic Compounds from Different Species of Solid Wood. Holz als Roh-und Werkstoff 1998, 56 (2), 125-129. https://doi.org/10.1007/s001070050282.

(53) Gray, C. M.; Monson, R. K.; Fierer, N. Emissions of Volatile Organic Compounds during the Decomposition of Plant Litter. J. Geophys. Res. 2010, 115 (G3), G03015. https://doi.org/10.1029/2010JG001291.

(54) Warneke, C.; Karl, T.; Judmaier, H.; Hansel, A.; Jordan, A.; Lindinger, W.; Crutzen, P. J. Acetone, Methanol, and Other Partially Oxidized Volatile Organic Emissions from Dead Plant Matter by Abiological Processes: Significance for Atmospheric $\mathrm{HO}_{x}$ Chemistry. Global Biogeochem. Cycles 1999, 13 (1), 9-17. https://doi.org/10.1029/98GB02428.

(55) Rantala, P.; Järvi, L.; Taipale, R.; Laurila, T. K.; Patokoski, J.; Kajos, M. K.; Kurppa, M.; Haapanala, S.; Siivola, E.; Petäjä, T.; Ruuskanen, T. M.; Rinne, J. Anthropogenic and Biogenic Influence on VOC Fluxes at an Urban Background Site in Helsinki, Finland. Atmos. Chem. Phys. 2016, 16 (12), 79818007. https://doi.org/10.5194/acp-16-7981-2016.

(56) Lange, B. M.; Ahkami, A. Metabolic Engineering of Plant Monoterpenes, Sesquiterpenes and Diterpenes-Current Status and Future Opportunities. Plant Biotechnol J 2013, 11 (2), 169-196. https://doi.org/10.1111/pbi.12022.

(57) Sharkey, T. D.; Yeh, S. Isoprene Emission from Plants. Annu. Rev. Plant. Physiol. Plant. Mol. Biol. 2001, 52 (1), 407-436. https://doi.org/10.1146/annurev.arplant.52.1.407.

(58) Wang, C.; Collins, D. B.; Arata, C.; Goldstein, A. H.; Mattila, J. M.; Farmer, D. K.; Ampollini, L.; DeCarlo, P. F.; Novoselac, A.; Vance, M. E.; Nazaroff, W. W.; Abbatt, J. P. D. Surface Reservoirs Dominate Dynamic Gas-Surface Partitioning of Many Indoor Air Constituents. Sci. Adv. 2020, 6 (8), eaay8973. https://doi.org/10.1126/sciadv.aay8973.

(59) Thanomsub, B.; Anupunpisit, V.; Chanphetch, S.; Watcharachaipong, T.; Poonkhum, R.; Srisukonth, C. Effects of Ozone Treatment on Cell Growth and Ultrastructural Changes in Bacteria. J. Gen. Appl. Microbiol. 2002, 48 (4), 193-199. https://doi.org/10.2323/jgam.48.193.

(60) Guzel-Seydim, Z. B.; Greene, A. K.; Seydim, A. C. Use of Ozone in the Food Industry. LWT - Food Science and Technology 2004, 37 (4), 453-460. https://doi.org/10.1016/j.lwt.2003.10.014.

(61) Schulz, S.; Dickschat, J. S. Bacterial Volatiles: The Smell of Small Organisms. Nat. Prod. Rep. 2007, 24 (4), 814. https://doi.org/10.1039/b507392h.

(62) Li, M.; Nian, R.; Xian, M.; Zhang, H. Metabolic Engineering for the Production of Isoprene and Isopentenol by Escherichia Coli. Appl Microbiol Biotechnol 2018, 102 (18), 7725-7738. https://doi.org/10.1007/s00253-018-9200-5.

(63) Sethia, P.; Ahuja, M.; Rangaswamy, V. Metabolic Engineering of Microorganisms to Produce Isoprene. 11 (419), 9.

(64) Schnitzler, J.-P.; Louis, S.; Behnke, K.; Loivamäki, M. Poplar Volatiles - Biosynthesis, Regulation and (Eco)Physiology of Isoprene and Stress-Induced Isoprenoids: Plant Volatiles of Poplar. Plant Biology 2009, 12 (2), 302-316. https://doi.org/10.1111/j.1438-8677.2009.00284.x.

(65) Vickers, C. E.; Possell, M.; Cojocariu, C. I.; Velikova, V. B.; Laothawornkitkul, J.; Ryan, A.; Mullineaux, P. M.; Nicholas Hewitt, C. Isoprene Synthesis Protects Transgenic Tobacco Plants from Oxidative Stress. Plant, Cell \& Environment 2009, 32 (5), 520-531. https://doi.org/10.1111/j.1365-3040.2009.01946.x.

(66) Velikova, V.; Fares, S.; Loreto, F. Isoprene and Nitric Oxide Reduce Damages in Leaves Exposed to Oxidative Stress. Plant, Cell \& Environment 2008, 31 (12), 1882-1894. https://doi.org/10.1111/j.1365-3040.2008.01893.x. 
(67) Vaida Valuntait; Šerevicien, V.; Girgždien, D.; Paliulis. Relative Humidity and Temperature Impact to Ozone And Nitrogen Oxides Removal Rate in The Experimental Chamber. Journal of Environmental Engineering and Landscape Management.

(68) Hoch, J. M. K.; Rhodes, M. E.; Shek, K. L.; Dinwiddie, D.; Hiebert, T. C.; Gill, A. S.; Salazar Estrada, A. E.; Griffin, K. L.; Palmer, M. I.; McGuire, K. L. Soil Microbial Assemblages Are Linked to Plant Community Composition and Contribute to Ecosystem Services on Urban Green Roofs. Frontiers in Ecology and Evolution 2019, 7, 198. https://doi.org/10.3389/fevo.2019.00198.

(69) Anderson, M.; Lambrinos, J.; Schroll, E. The Potential Value of Mosses for Stormwater Management in Urban Environments. Urban Ecosystems 2010, 13, 319-332.

(70) Ander, P.; Eriksson, K.-E. Methanol Formation during Lignin Degradation by Phanerochaete Chrysosporium. Applied Microbiology and Biotechnology 1985, 21 (1), 96-102. https://doi.org/10.1007/BF00252369.

(71) Zhang, Junfeng.; Wilson, W. E.; Lioy, P. J. Indoor Air Chemistry: Formation of Organic Acids and Aldehydes. Environ. Sci. Technol. 1994, 28 (11), 1975-1982. https://doi.org/10.1021/es00060a031.

(72) Glasius, M.; Lahaniati, M.; Calogirou, A.; Di Bella, D.; Jensen, N. R.; Hjorth, J.; Kotzias, D.; Larsen, B. R. Carboxylic Acids in Secondary Aerosols from Oxidation of Cyclic Monoterpenes by Ozone. Environ. Sci. Technol. 2000, 34 (6), 1001-1010. https://doi.org/10.1021/es990445r.

(73) Morrison, G. C.; Nazaroff, W. W. Ozone Interactions with Carpet: Secondary Emissions of Aldehydes. Environ. Sci. Technol. 2002, 36 (10), 2185-2192. https://doi.org/10.1021/es0113089.

(74) Nawrocki, J.; Świetlik, J.; Raczyk-Stanisławiak, U.; Dąbrowska, A.; Biłozor, S.; llecki, W. Influence of Ozonation Conditions on Aldehyde and Carboxylic Acid Formation. Ozone: Science \& Engineering 2003, 25 (1), 53-62. https://doi.org/10.1080/713610650.

(75) US Environmental Protection Agency. Health Assessment Document for Acetaldehyde. 1987.

(76) Thompson, M. Administered by Inhalation to F344/N Rats and B6C3F1 Mice. Toxicity Report Series No. 19, 62. 1992.

(77) Bergmans, L.; Moisiadis, P.; Van Meerbeek, B.; Quirynen, M.; Lambrechts, P. Microscopic Observation of Bacteria: Review Highlighting the Use of Environmental SEM. Int Endod J 2005, 38 (11), 775-788. https://doi.org/10.1111/j.1365-2591.2005.00999.x.

(78) Solomon, S. J.; Schade, G. W.; Kuttippurath, J.; Ladstätter-Weissenmayer, A.; Burrows, J. P. VOC Concentrations in an Indoor Workplace Environment of a University Building. Indoor and Built Environment 2008, 17 (3), 260-268. https://doi.org/10.1177/1420326X08090822.

(79) Zhang, J.; Wilson, W.; Lioy, P. Sources of Organic Acids in Indoor Air: A Field Study. Journal of exposure analysis and environmental epidemiology 1994, 4 (1), 25-47. 